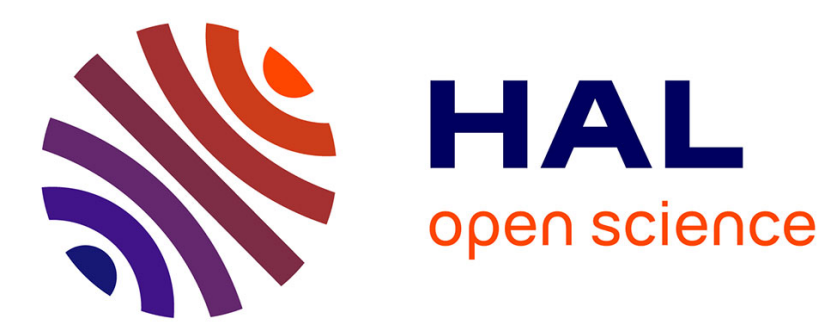

\title{
The geographical distribution of typologically diverse comparative constructions of superiority in Purepecha
}

Claudine Chamoreau

\section{To cite this version:}

Claudine Chamoreau. The geographical distribution of typologically diverse comparative constructions of superiority in Purepecha. 2009. halshs-00672270

\section{HAL Id: halshs-00672270 \\ https://shs.hal.science/halshs-00672270}

Preprint submitted on 20 Feb 2012

HAL is a multi-disciplinary open access archive for the deposit and dissemination of scientific research documents, whether they are published or not. The documents may come from teaching and research institutions in France or abroad, or from public or private research centers.
L'archive ouverte pluridisciplinaire HAL, est destinée au dépôt et à la diffusion de documents scientifiques de niveau recherche, publiés ou non, émanant des établissements d'enseignement et de recherche français ou étrangers, des laboratoires publics ou privés. 


\title{
The geographical distribution of typologically diverse comparative constructions of superiority in Purepecha ${ }^{1}$
}

\author{
Claudine Chamoreau \\ CNRS (CEMCA - SEDYL/CELIA) \\ claudine@vjf.cnrs.fr
}

\begin{abstract}
This paper explores the relations between three domains dealing with linguistic variation: dialectology, typology, and contact linguistics. It aims to contribute to dialectal research that also considers syntactic questions, exploring the syntactic domain of comparative constructions of superiority in Purepecha (a language isolate spoken in Mexico). I demonstrate that the expression of the comparison of superiority can be mapped onto the language by means of ten constructions, which may be divided into four types, showing that language contact can lead to the emergence of new types. This study points out that the consequences of language contact are not homogeneous, but fall into various types of construction aligned with local specificities and geographical distribution. I argue that the integration of dialectology, typology, and contact linguistics results in a dynamic and multi-dimensional organization, which I characterize as a multi-layered perspective.
\end{abstract}

Key words: dialectology, typology, contact linguistics, comparison of superiority, Purepecha

\section{Introduction}

The aim of this paper is twofold. First, it contributes to typological research that brings in dialectal questions. I propose a systematic and detailed comparison of very closely related speech varieties in order to identify fine distinctions and hence to develop a more fine-grained typology. I explore the syntactic domain of comparative constructions of superiority in Purepecha (a language isolate spoken in Mexico). I demonstrate that the expression of this comparison can be mapped onto

\footnotetext{
${ }^{1}$ This is a revised version of a paper originally presented in November 2007 at the Primer seminario de complejidad sintáctico at the University of Sonora (Mexico). I am very grateful to members of this audience who provided relevant comments. I also would like to acknowledge with gratitude the comments of Bernard Comrie and an anonymous reviewer on an earlier draft. Thanks too to Odile Hoffmann and Rodolfo Avila for helping me draw the maps.
} 
the language by means of ten constructions, which may be divided into four types: the particle type, particle type with a locative phrase, mixed coordination and particle type, and applicative type. This study highlights constructions (the applicative type and a construction of the particle type with a locative phrase) that have not been taken into account in other cross-linguistic studies referred to (Andersen 1983; Stassen 1985; Heine 1997; Cuzzolin and Lehmann 2004).

Second, I show that these constructions display a geographical distribution unlike that which Friedrich $(1971,1975)$ and Chávez (2004) established for Purepecha, as they argued for the absence of dialectal areas and the presence of a "pueblo dialectology" (Friedrich 1971: 169). I propose that by exploring the typological variety of syntactic constructions in Purepecha it will be possible to identify dialectal areas (Kortmann 2004, Nevelainen et al. 2006, Chamoreau 2009a, 2012a). This study also takes account of contact-induced changes in order to highlight the dynamic aspects of this construction. In Purepecha, the consequences of language contact are not homogeneous, but break down into various types of comparative constructions of superiority that are geographically specific. The adoption of Spanish comparative constructions differs from area to area. In other words, each type has an identifiable geographical distribution. Moreover, a syntactic focus with respect to dialectal research reveals the dynamic of Purepecha, showing contact-induced changes and synchronic variations and highlighting social and historical particularities. This dialectal perspective is thus not static but dynamic and multi-dimensional, that is, multi-layered, demonstrating three complementary levels of organization.

This paper is organized as follows: Section 2 gives some basic typological properties of Purepecha; section 3 introduces essential information on dialectological features; section 4 presents comparative constructions in Spanish, the model language, and in Lengua de Michoacan, the pre-contact replica language $^{2}$; section 5 illustrates the diversity and complexity of comparative constructions in Purepecha; and section 6 focuses on geographical distribution, highlighting the dynamic multi-layered organization.

\footnotetext{
${ }^{2}$ In order to distinguish the pre-contact replica language from the contact replica language, I adopt the traditional name, Lengua de Michoacan, for the former, the language spoken in the sixteenth century, and the current name, Purepecha, for the latter.
} 


\section{Some properties of Purepecha}

\subsection{The language and its speakers}

Purepecha (formerly known as Tarascan) is classified as a language isolate spoken in the state of Michoacan in the central western part of Mexico, with approximately 110,000 speakers, $10 \%$ of them monolingual (Chamoreau 2009a). Spanish is the language of prestige, linked to education, a better standard of living, oral and written media, religion, administration, commerce, and work. In 2003, Purepecha (like the other indigenous languages spoken in Mexico) acquired the status of a national language.

Purepecha presents a geographical continuum of speakers, and the different ways of speaking Purepecha are inter-intelligible to varying degrees. Purepecha is traditionally spoken in Michoacan in a territory of $3500 \mathrm{~km}^{2}$. The area includes 80 villages divided into 21 municipalities, and is generally divided into four geographic regions (see map $\left.1^{3}\right)$ :

(i) In the northeast, the region of Zacapu is a small area with $5.2 \%$ of the speakers. Only in two villages, Zipiajo and Azajo, does the language have a high degree of vitality (more than $97 \%$ of Purepecha speakers); in the other communities Purepecha is not the everyday conversation language and is not transmitted to the youngest inhabitants.

(ii) In the east, the region of Lake Patzcuaro is the most accessible one, with most exposure to economic and tourist development. It is home to $17.8 \%$ of the speakers. In this region, the language is losing ground, except in two islands, Yunuen and Tecuen, and in some villages to the north of the lake, such as Santa Fe de la Laguna, Chupícuaro, and San Andrés Tziróndaro. Tecuen and Santa Fe de la Laguna exhibit great vitality and are made up of more than 94\% Purepecha speakers; the people - even the youth - speak Purepecha in everyday conversation. The other four villages contain more than $57 \%$ Purepecha speakers.

\footnotetext{
${ }^{3}$ In map 1 only the villages where I am working are indicated.
} 
(iii) In the northwest, the valley of the eleven villages has $14.7 \%$ of the speakers. All the villages are along a road and are very close to one another; it is possible to go from one village to another simply by crossing the street. Each village preserves its identity, but as a consequence of their proximity they share some feasts and some traditional and economic activities. In these villages, Purepecha has a high degree of vitality; they contain more than $94 \%$ Purepecha speakers (except in Chilchota).

(iv) The most important and central region, the Sierra, represents $62.3 \%$ of the speakers. The preservation and transmission of the language is still intense in this region. The region is extensive and sub-regions can be distinguished, for example the villages in the southeast (Comachuen, Arantepacua, Turicuaro, Quinceo), in the center, the villages whose begins with San (San Isidro, San Benito, San Marcos, etc.). Each sub-region has its own internal organization and some links with villages throughout the region. In some geographically isolated villages, Purepecha has a high degree of vitality: Ocumicho (in the north, 85\% Purepecha speakers), Tarecuato (in the west, 77\%), Cocucho (in the center, 87\%), and Angahuan (in the south, 96\%).

\subsection{Basic typological properties}

Purepecha is an agglutinative and synthetic language, and is almost exclusively suffixing. It has an elaborate derivational verbal system. Although bare stems exist, there is a very productive derivational system in which a basic stem can take voice, causative, locative, positional, directional, and adverbial derivative suffixes. Inflectional suffixes follow the stem to mark aspect, tense, mood, and person (Chamoreau 2009a).

Purepecha has nominative-accusative alignment, and is a case-marking language in which the nominal subject has no overt marker. The object is generally marked by the objective case marker - $n i$. This morpheme encodes the object of a transitive verb, such as misitu-ni 'the cat,' in (1), and both objects of a ditransitive verb, such as inte-ni wantantskwa-ni and Puki-ni, in (2). The presence or absence of the object case marker 
depends on semantic hierarchy (animacity), grammatical features (definiteness, etc.), and pragmatic strategies (topic, focus).

\begin{tabular}{|c|c|c|c|c|}
\hline xo & Selia & $a t a-x-t i$ & imeri & misitu-ni \\
\hline yes & Celia & beat-AOR-ASS3 & POS3 & cat-OBJ \\
\hline
\end{tabular}

(2)

$\begin{array}{lllll}\text { Selia } & \text { arhi-x-ti } & \text { inte-ni } & \text { wantantskwa-ni } & \text { Puki-ni } \\ \text { Celia } & \text { tell-AOR-ASS3 } & \text { DEM-OBJ } & \text { story-OBJ } & \text { Puki-OBJ } \\ \text { 'Celia told Puki a story.' (JR-A25: 36) } & & \end{array}$

Subject and object pronouns are expressed by second-position enclitics. Purepecha displays predominance of dependent-marking (for example, the pronominal enclitic and genitive case). Purepecha is basically a SV and SVO constituent order language, as illustrated by examples (1) and (2). This order, that is, the one that is pragmatically unmarked, is the basic order in the region of Lake Patzcuaro (Capistrán 2002, Chamoreau 2009a: 55-58). Other orders indicate specific pragmatic properties. Studies of constituent order in the other regions do not as yet exist (Chamoreau 2009b). However, Purepecha shows some traits of a SOV language: (i) tense, aspect, and modal markers following the verb; (ii) postpositions; (iii) the almost exclusive use of suffixes; (iv) enclitics; (v) case markers; (vi) main verbs preceding inflected auxiliaries. SVO and SOV constituent orders are attested in the sixteenth century, and the former has progressively increased since then. The change is probably due to areal contact. Spanish has been the principal contact language for many centuries; however, prior to the Conquest there were speakers of other languages in this territory, mostly from Nahuatl (Uto-Aztecan family) and Otomi (Otopamean family), two languages with verb-initial structure. The change probably began under the influence of these languages; Spanish, a SVO language, continued the process, for example by introducing prepositions (Chamoreau 2007).

\footnotetext{
${ }^{4}$ The examples of Purepecha come from my own fieldwork data. The first letter corresponds to the pueblo, here JR; then appears the file identifier, here A25, and finally the reference of the recording, here 94.
} 


\section{Dialectology of Purepecha}

Paul Friedrich (1971, 1975) and David Chávez (2004) have sketched tendencies establishing some correlations between the linguistic data and geographic distribution. However, the overall results have pointed to a process of breakdown in which the isoglosses cross each other and fail to define dialectal areas.

In his study, Friedrich (1971: 169) concludes that "the pervasive and distinctive features of Tarascan dialectology are (1) the implicit equality of village dialects, (2) the mutual distinctiveness of village dialects, (3) differential exposure, mainly after the age of five, to the Spanish of the dominant Mestizo world, and (4) near lack of covariation between linguistic and gross geographical marginality. Similar combinations obtain elsewhere in the world, but are so characteristic of Indian Mexico, including Mayan Chiapas, that I have coined the term "pueblo dialectology'." In other words, every village has its own way of speaking Purepecha; the language is one of the identity features used to display and assert that someone belongs to a particular village. Suárez (1983: 19-20) indicates that this situation reflects the linguistic fragmentation in Mesoamerica. He claims that "Pueblo dialectology" is also described in Tseltal, Tsotsil, and Quichean languages.

Chávez (2004: 112) even claims that there are no features specific to each village, but perhaps only speaker-specific features. He concludes by questioning the relevance of the study of dialectology for this language (for a detailed analysis of these two studies, see Chamoreau 2005). Given the lack of clear geographical distribution for the linguistic data, Chávez's question is relevant. The situation he describes does not make it possible to define linguistic areas. Some of the methodological choices adopted by Friedrich and Chávez may explain their results. Three facts are relevant. Firstly, they worked in only a few villages - Friedrich in 26 (32.5\% of the villages) and Chávez in 10 (12.5\% of the villages). Secondly, they only used questionnaires translated from Spanish, and thirdly, they worked essentially on the phonetic and lexical levels (with some morphological data).

In this paper I explore a specific syntactic construction, the variation of comparative constructions of superiority; however, in the course of the 
investigation $^{5}$ other syntactic constructions are also analyzed as well as phonological and morphological features (Chamoreau 2009a, 2012a). This investigation is part of a project that aims to document the different ways of speaking Purepecha. So far, I have studied 60 villages located in 21 municipalities, accounting for $70 \%$ of the villages in which the language is spoken. In each village, I recorded three men and three women, belonging to three age groups (15-29, 3049, 50 and older). The method I adopted was to record five types of data (during approximately 15 hours in each village):

(i) Traditional narratives, descriptions of specific situations, spontaneous speech;

(ii) Conversations between two or three people from the same village or from different villages;

(iii) 200 sentences (translated from Spanish), designed to cover all relevant areas of morphosyntax;

(iv) Sociolinguistic questionnaires (about each village and each speaker) asked in Purepecha;

(v) Attitude questionnaires (perceptual dialectology) also asked in Purepecha. The data collected by the team that took part in the project was compiled, translated, and classified in a large database.

\section{The comparative construction of superiority: model and pre-contact replica languages}

Stassen (1985: 24, 2001: 993, 2005: 490) defines comparison in cognitive terms, "as a mental act by which two objects are assigned a graded position on a predicative scale. If the positions on the scale are different, then we speak of comparison of inequality." Comparison may thus be understood as a cognitively complex "activity" that needs different categories in order to be expressed. In this paper, I consider explicit comparison, that is, constructions that involve at least the two entities compared, the comparee NP and the standard NP, and one quality, and

\footnotetext{
${ }^{5}$ This research was made possible through financial support from the French and Mexican institutions CELIA, SEDYL, CEMCA, and INALI. Aid from these institutions is greatly appreciated. This research would not have been possible without the support of Teresa Ascencio Domínguez, Puki Lucas Hernández, Celia Tapia, and all our Purepecha hosts.
} 
constructions that express inequality between the two entities being measured. This construction may also involve a degree marker and a comparative relator, as in English, in (3)

(3) This tiger is more foolish than my dog

$$
\mathrm{C}_{\text {ompare }} \mathrm{D}_{\text {egree }} \mathrm{Q}_{\text {uality }} \mathrm{R}_{\text {elator }} \mathrm{S}_{\text {tandard }}
$$

Comparative constructions have been studied cross-linguistically, and while "the process of comparison is an essential semantic mechanism" (Pottier 1982: 41), it is generally recognized that not all languages have a specific construction and that each language elaborates its own strategies in order to express comparison (Creissels 2006: 211; Heine 1997: 122, Cuzzolin and Lehmann 2004). Generally, four types are described (Chamoreau 2009a):

1. The coordination type. This type involves the juxtaposition or coordination of two entities with no specific marker of comparison. There are two subtypes: in the first subtype, two antonymic qualities are generally joined by means of an adversative coordinator or are juxtaposed, as in Pima Bajo (4). In the second subtype, there is positive-negative polarity, as in Oxchuc Tseltal (5).

(4) Pima Bajo (Uto-Aztecan, Estrada Fernández 2006)

$\begin{array}{lllll}\text { hïg } & \boldsymbol{s i}, & \text { gïid } \text { aan } & \text { si' } & \text { liidi } \\ \text { 3SG.SBJ } & \text { INTS } & \text { big.APP 1SG.IND } & \text { INTS } & \text { small.APP }\end{array}$

'He's bigger than I.' (Lit. 'He is very big, I am very small'

(5) Oxchuc Tseltal (Mayan, Cruz Gómez 2008, p.c.)

$$
\begin{array}{lllll}
j a^{\prime}-\phi & \text { najt' } & \text { xan te } & \text { Melisa }=e & j a^{\prime}-\phi \quad \text { komkomtik } \\
\text { FOC-B3 } & \text { long } & \text { more DET } & \text { Melisa }=\mathrm{CL} & \text { FOC-B3 short } \\
\text { xan } & \text { te } & s \text {-tat }=e & & \\
\text { more } & \text { DET } & \text { A3-father }=\mathrm{CL} & &
\end{array}
$$

'Melisa is taller than her father.' (Lit. Melisa is who is longer, her father is who is shorter.') 
2. The adjunct clause type. This type is very frequent among the languages of the world. The standard NP generally occurs as an adjunct with a case marker, coinciding with certain cases; the ablative, as in Tunumiisut (6), and locative, as in Jacaltec (7), are the most frequent subtypes. These constructions have in common the fact that the standard NP is conceptualized in terms of spatial relationships.

(6) Tunumiisut (Eskaleut, Tersis 2008: 316)

isima-qaq-taq-nhatiwaq-pu-a kuummiit

thought-have-HAB-however-INDIC-1SG Kuummiit

tasiita-minhnhaaniit ani-tii-tiq-1jumaaq-tiq

Tasiilaq-ABL be.big-COMPAR-INCH-FUT-ATTRIB

'I often thought that Kuummiit would be bigger than Tasiilaq.' (Lit. 'I often thought that Kuummiit would be bigger from Tasiilaq.'

(7) Jacaltec (Mayan, Craig 1977: 39)

$\mathrm{ka}^{\prime} \quad$ icham hin s-sataj naj Pel

more old I him-in.front CL Peter

'I am older than Peter.' (Lit. 'I am older in front of Peter.')

3. The verbal type. The comparee $\mathrm{NP}$ is characterized as a kind of agent while the standard NP is portrayed as a kind of patient. The verb is generally (but not always, see Heine 1997: 112-114) an action verb that carries the notion of 'surpass,' 'win over,' 'exceed' as a degree marker. The expression of comparison here involves syntax rather than morphology, as in Classical Nahuatl (8).

(8) Classical Nahuatl (Uto-Aztecan, Launey 1981: 312)

ni-mitz-pana-huia in ìtech chicāhuacāyōtl

1-2OBJ-pass-APP DET within strength

'I am stronger than you.' (Lit. 'I surpass you within strength.') 
4. The particle type. This type contains several constructions that feature a degree marker accompanying the quality and a relator accompanying the standard, as in (9), with a synthetic form, such as -er in English, in (9a) or an analytic one, such as more, in (9b).

(9) a. This man is taller than his brother

b. A tiger is more ferocious than a dog

In order to understand the different constructions, and to analyze the difference between the impact of contact and that of internal change, it is relevant to show the diversity of constructions attested in Spanish, the model language, and in Lengua de Michoacan, the pre-contact replica language.

\subsection{Spanish, the model language}

Spanish has had and has various types of comparative constructions. I will present here the most frequent constructions used in the sixteenth century, the time of contact between Lengua de Michoacan and Spanish. The most frequent and less marked is the particle construction that has a degree marker más 'more' and a relator, que 'than' (Galant 1998; Rojas Nieto 1990a, 1990b). The comparee NP is the subject, and the standard NP is expressed after the quality and appears after the relator que. In (10), the degree marker comes before the quality with the be-verb and the adjective. In (11) where quality is expressed by the verb corre 'run,' the degree marker comes after the verb and next to the comparative marker.

(10) Spanish

$\begin{array}{lclll}\text { María es más } & \text { alta que Juan } \\ \text { Mary be.PRES3 } & \text { more } & \text { tall.FEM than John }\end{array}$

'Mary is taller than John.' 
(11) Spanish

mi perro corre más que tu gato

POS1 dog run.PRES3 more than POS2 cat

'My dog runs more than your cat.'

In Spanish this type coexists with another type, described as a marked type, in which the de preposition appears, as can be observed in (12).

(12) Spanish (Rojas Nieto 1990b: 226)

$\begin{array}{lllll}\text { es } & \text { más } & \text { grande } & \text { de lo normal } \\ \text { be.PRES3 } & \text { more } & \text { tall } & \text { of } & \text { DEM normal }\end{array}$

'He is taller than normal.'

The difference is that the más...que construction appears before all clause types, whereas the más...de construction shows restriction in use. Rojas Nieto (1990b) notes that this construction is found before relative clauses, as in (13):

(13) Spanish (Rojas Nieto 1990b: 229)

mandaron más libro-s de lo-s que pedí

send.PAST.3PL more book-PL of DEM.MASC-PL than ask.for.PAST.1

'They sent more books than I asked for.' (Lit. 'They sent more books of those than I asked for.')

This más...de construction shows the cognitive relation between comparison and location meaning (Rojas Nieto 1990b; Stassen 1985). The standard NP is conceptualized in terms of spatial relationships.

A third comparative construction exists in Spanish, classified as a verbal type since it involves lexical concepts that use the idea of surpassing as a degree marker, as in (14). The comparee NP is the subject el duque and the standard NP is the object $l o$. 
(14) Spanish (Rojas Nieto 1990a: 449)

$\begin{array}{lllll}\text { el duque sólo lo supera en linaje } \\ \text { the duke } & \text { only } & \text { him surpass-PRES3SG in lineage }\end{array}$

'Only the duke surpasses him in lineage.'

In Spanish, this construction is marked and generally used when speakers want to insist on the meaning of the verb, for example an action verb that carries the notion of 'surpass' as in example (14).

\subsection{Lengua de Michoacan, the pre-contact replica language}

There are two types of construction; both have a jats- 'surpass' verb that expresses degree. These constructions correspond to the synthetic and the derivational morphological characteristics of the language: the verb is modified by the causative $-t a$ and by a suffix expressing transfer - $m a$. The first construction is a clear verbal type. In (15), the comparee NP, Pedro is the subject and the standard NP Jwano-ni is the direct object. The quality is expressed by a non-finite verb ampake-ni that functions as a complement clause. The quality appears after the standard NP, which is generally a sign of OV languages (Andersen 1983: 99-138, Dryer 2007).

(15) Lengua de Michoacan (Isolate, Gilberti 1987 [1558]: 109)

Pedro hatztamahati Juanoni ambaqueni

Pedro jats-ta-ma-ja-ti Jwano-ni ampake-ni

Peter put-CAUS-TRANSF-PRES-ASS3 John-OBJ be good-INF

'Peter is better than John.' (Lit. 'Peter surpasses John (in) be(ing) good.')

The second construction is a mixed type that combines a verbal type and a coordination type. In (16), the first clause contains the comparee NP, the subject Pedro 'Peter,' the verb jats 'surpass,' and the object, the non-finite verb ampake-ni 'be good,' which functions as an argument of the main verb, a complement clause. The second clause is introduced by the coordinator $k a$. The negation no indicates that the standard NP lacks the property. The adverb isi 'like that' and the negation 
no operate the semantic reference with the verb jats-ta-ma 'surpass.' In the second clause, there is no verb, showing a stripping strategy.

(16) Lengua de Michoacan (Isolate, Gilberti 1987 [1558]: 109)

Pedro hatztamahati ambaqueni ca noys Juan

Pedro jats-ta-ma-ja-ti ampake-ni ka no isï Jwanu

Peter put-CAUS-TRANSF-PRES-ASS3 be good-INF and NEG so John

'Peter is better than John.' (Lit. 'Peter surpasses in being good, and John (is) not like that.')

\section{Comparative constructions in Purepecha}

In Purepecha, comparison of superiority is mapped out by means of ten constructions, which can be grouped into four types:

- Particle type (4 sub-types)

- Particle type with a locative clause (3 sub-types)

- $\quad$ Mixed coordination and particle type (2 sub-types)

- Applicative type (1 sub-type)

\subsection{The particle type $(P)$}

The particle construction consists of one clause in which the comparee NP is encoded as the subject of the predicate, whereas the standard NP, which has no case marker, appears after the comparative relator $k e^{6}$ or the complementizer ixki (or its variants exka). The quality is generally encoded by a verb, as in (18) and (19), but also by an adverb, as in (17), or an adjective, as in (20). The order follows the Spanish order. The degree marker may be the Spanish marker mas or the

\footnotetext{
${ }^{6}$ One possible hypothesis is that $k e$ is borrowed from Spanish because the form and the function are similar to the Spanish particle que. Nevertheless, another possibility is convergence or syncretism between the Spanish $k e$ and the native Purepecha relator $k i$. This relator appears in various particles such as the complementizer ixki or the subordinator enki. Convergence or syncretism between the two elements might have been favored because they exhibited a similar form and functioned in similar contexts. This topic has not yet been studied. Nevertheless, in the comparative constructions, we can assume that $k e$ is borrowed for this function, as the entire comparative construction is borrowed or replicated.
} 
Purepecha morpheme sániteru, which means 'more.' This type presents four subtypes:

P1. Particle constructions with the degree marker mas and the comparative marker ke

The first subtype is a clear grammatical borrowing in which both the structure, i.e., the particle construction, and the phonetic substance, that is the Spanish, mas and ke appear in Purepecha.

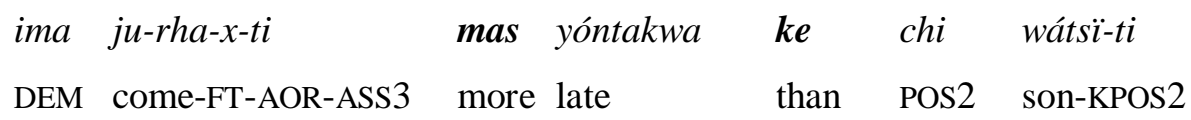

'He came later than your son.' $\quad$ (JR-C28: 170)

P2. Particle constructions with the degree marker sániteru and the comparative marker eska or exki

This is a grammatical replication in which we recognize the Spanish construction; however, the specific morphological elements are not borrowed from Spanish but are taken from the native language, Purepecha. In (18) the degree marker and the comparative marker are the Purepecha morphemes. The degree marker, sániteru, is analyzed as sáni 'few,' plus the clitic =teru 'more' and the particle eska 'than.'

$\begin{array}{lllll}\text { nanaka-echa } & \text { sáni=teru } & \text { tere-kuri-xin-ti } & \text { eska=ni } & j i \\ \text { girl-PL few=more } & \text { laugh-MID-HAB-ASS3 } & \text { than=1 } & \text { 1IND } \\ \text { 'The girls are laughing more than me.' (AR-E7: 99) } & & \end{array}$

P3. Particle constructions with the degree marker sániteru and the comparative marker ke

In (19), we find a particular situation in which only one grammatical item is borrowed, namely the marker, $k e$, while the degree marker is the Purepecha 
morpheme sániteru. It is thus a mixture of borrowing and grammatical replication. Logically, two possibilities exist:

- borrowing the degree marker mas, and using the marker ixki

- $\quad$ using the degree marker sániteru, and borrowing the marker, ke.

In the data, only the second option is found. In (19), we observe the same order as presented in the examples above; the quality is placed between the degree marker and the marker.

$\begin{array}{llll}\text { (19) } & i & \text { kamisa } \text { sáni=teru } & \text { juka-para-s-ti } \\ \text { DEM } & \text { shirt } & \text { few=more } & \text { put-shoulder-AOR-ASS3 } \\ \boldsymbol{k} \boldsymbol{e} & i x u & \text { anapu-e-s-ti } & \\ \text { than } & \text { here } & \text { origin-PRED-AOR-ASS3 }\end{array}$

'This shirt is more expensive than the one made here.' (IH-A1: 39)

P4. Particle constructions with the degree marker sániteru and the comparative markers ke and exka

In this fourth subtype, the two comparative markers ke and exka coexist in the same construction. This is perhaps additional evidence that $k e$ is borrowed from Spanish in this context (see footnote 6). This redundancy could show, as indicated by Lindenfeld for Yaqui (1971: 10), that "speakers feel the need to have a COMPLEX marker for every type of comparative ...." In Purepecha, another explanation is also possible. The speakers have adopted the Spanish comparative construction with the Purepecha degree marker sániteru and the comparative marker ke (subtype P3), and in order to "Purepechize" this construction or to give it a more Purepecha-like feel, they add the Purepecha comparative marker exka.

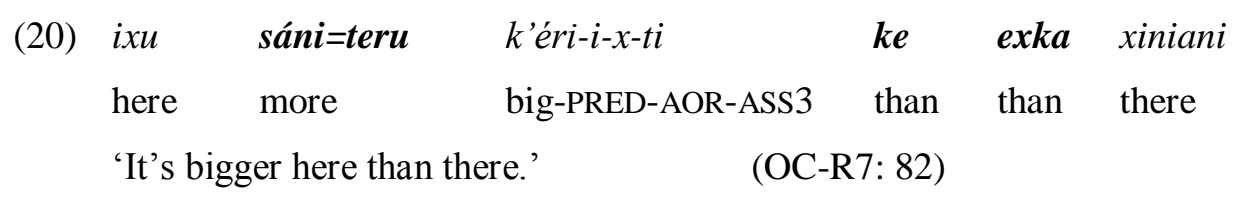


These four subtypes are clear examples of contact-induced restructuring and convergence with Spanish and also indicate that the language has come to use a new strategy, taking morphological categories to express the degree marker and the comparative particle. Moreover, the quality is no longer expressed by a non-finite verb but by a verb, an adjective, or an adverb. Particle constructions are most widespread in Europe (Stassen 1985; Heine 1994). Stolz and Stolz (1995, 2001) claim that "Hispanicization of comparative constructions was almost commonplace among the indigenous languages of Mexico, Guatemala, Belize, Honduras, Nicaragua, and El Salvador" (2001: 38).

\subsection{The particle type with locative clauses $(P L)$}

The basic construction here is that of the particle type. The original feature of type PL is the presence of a preposition accompanying the standard NP. Two possibilities exist:

- A source subtype (PL1 and PL2) in (21) and (22), with the Spanish preposition $d e$ 'from.' The standard NP is marked as the source of a movement.

- A static subtype (PL3) in (23), with the Spanish preposition entre 'between.' This preposition is a particular illustration of the static locative type.

It is interesting to note that the two prepositions are Spanish prepositions; Purepecha has only postpositions. The Spanish prepositions de and entre are not loan words because they never occur alone with the semantic features they have in Spanish. They only appear in Spanish insertion clauses like de veras 'really, truly,' or la seis de la mañana 'six in the morning.' Purepecha has postpositions and case markers that generally satisfy the use contexts of the Spanish prepositions $d e$ and entre.

In the source subtypes, in (PL1) and (PL2), the difference resides in the use of the Spanish degree marker mas, in (21), or the use of the Purepecha degree marker sániteru, in (22). In the static subtype, in (PL3), only a construction with the Spanish degree marker mas is found, in (23). 
PL1. Particle type with the degree marker mas and a locative clause
(21) inte acha mas k'éri-e-s-ti ke de xo anapuyamintu
DEM man more old-PRED-AOR-ASS3 than of here originall
'This man is older than anyone else here.' (Lit. 'This man is older than of all the others from here.') (TM-C1: 301)

PL2. Particle type with the degree marker sániteru and a locative clause
(22) pedru sáni=teru prontu jano-nku-ti ke de t'u
Peter few=more quickly arrive-CENTRIP-ASS3 than of 2IND

'Peter arrives more quickly than you.' (Lit. 'Peter arrives more quickly than of you.') (CN-E9: 102)

PL3. Particle type with the degree marker mas and a locative clause
(23)
Puki mas kokani jano-nka-ti ke entre ima
Puki more quickly arrive-CENTRIP-ASS3 than between DEM
'Puki arrives more quickly than him.' (Lit. 'Puki arrives more quickly than between him.') (SA-N1: 101)

This shows the creation of a new type, using a process that is not attested in Lengua de Michoacan: the use of a locative phrase with the particle construction. This construction with the preposition $d e$ is attested in Spanish, but the order and the conditions of use are different from Purepecha. This construction does not have the semantic and syntactic restrictions it shows in Spanish (see section 4.1), and it is the unmarked type in various villages, while in Spanish it is a marked construction (see below, section 6). Purepecha speakers have apparently innovated the construction with entre, since Spanish has no comparative construction of superiority with the preposition entre. There is no correlation with other structures in Purepecha, as entre is only used in this construction, and there is no comparative construction in pre-contact replica Lengua de Michoacan with a locative pattern that might be used as a model. Purepecha displays a use of comparative constructions with entre that deviates from the patterns of comparative construction 
in Spanish and from the use of entre in Spanish. The transfer of Spanish entre allows Purepecha to innovate in the expression of the comparison of superiority and in the context of the use of this Spanish preposition (Chamoreau 2012b).

\subsection{The mixed coordination and particle type $(C P)$}

This mixed type exhibits the combination of two constructions. The basic construction is the coordinated positive-negative polarity in which the comparee NP has the property while the standard NP lacks the property. The coordination construction has a structure similar to the one attested to in the sixteenth century (see example 16); the particle construction combines with the coordination one, but exhibits only one feature of this type, the degree marker.

This mixed type is formed by two clauses. The first one contains the comparee NP kumanchikwarhu incharini in (24) and Petu in (25), the degree marker mas in (24) and sániteru in (25), and the quality jorhepekwa jarhasti in (24) and yót'arhaxïnti in (25). The second clause is introduced by the coordinator $k a$. The negation no indicates that the standard NP lacks the property. This clause has a stripping structure: the verb is deleted, signifying that it is identical to the verb in the first clause. There are two subtypes, defined according to the two degree markers, the Spanish mas in CP1 and the Purepecha sániteru in CP2.

CP1. The coordination type with the degree marker mas

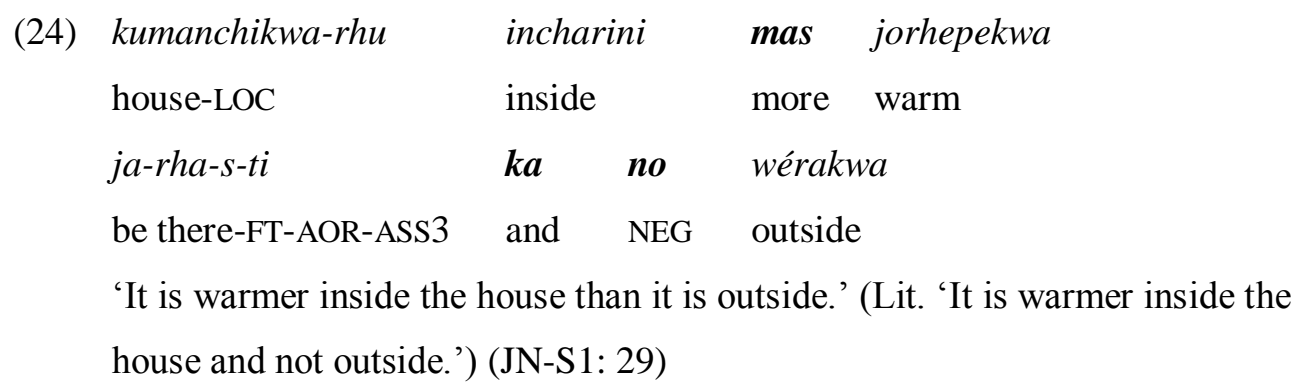


CP2. The coordination type with the degree marker sániteru

$\begin{array}{lllll}\text { Petu sáni=teru } & \text { yó-t'a-rha-xïn-ti } & \boldsymbol{k a} & \text { no } & \text { Maria } \\ \text { Peter few=more } & \text { be long-leg-FT-HAB-ASS3 } & \text { and } & \text { NEG } & \text { Mary }\end{array}$

'Peter is taller than Mary.' (Lit. 'Peter is taller and not Maria.') (JR-M2:

319)

This construction is a clear consequence of the restructuring of the comparative construction domain in Purepecha. This mixed type shows internal evolution and contact-induced change. The former is indicated by the fact that the coordination construction is maintained (see example 16 in Lengua de Michoacan), while the latter is illustrated by the process through which verbal type is lost in favor of particle constructions.

\subsection{The applicative type $(A)$}

This type has only one construction, expressing quality through a synthetic derivative structure. In (26a), the basic construction, the quality is expressed by an adjective $k$ 'éri 'big, tall, old,' accompanied by a predicativizer $e$. In (26b), k'éri is modified by the applicative morpheme $k u$, which increases the valence and introduces another argument imeri pirimpani 'his sister,' which is the syntactic object, and which has the role of the possessor of the quality. The subject Petu 'Peter' is the comparee NP, while the object imeri pirimpani 'his sister' is the standard NP. The superiority degree is a consequence of the modification by the applicative morpheme.

\footnotetext{
(26)a. Petu k'éri-e-x-ti

Peter big-PRED-AOR-ASS3

'Peter is big (tall or old).'
} 


$$
\begin{array}{clll}
\text { b. Petu } & \text { khéri-e-ku-x-ti} & \text { imeri } & \text { piri-mpa-ni } \\
\text { Peter } & \text { old-PRED-3APPL-AOR-ASS3 } & \text { POS3 } & \text { sister-POSP3-OBJ }
\end{array}
$$

'Peter is older than his sister.' (Lit. 'Peter applies his old age to his sister.') (CC-F3: 401)

This construction is marginal for two reasons: i) it is accepted only in two of the villages in our sample (Carapán and Cucuchucho), and ii) it is accepted only with a few adjectives, $k$ 'éri 'big, tall, old,' urape 'white,' and axpe 'good (for food).'

Foster (1969: 128) illustrates this construction with many adjectives: urape 'white,' winape 'good,' and axpe 'good.' But her translations are problematic, as winape means 'strong' and not 'good' as she claims, and axpe means 'good, tasty,' only used for food, and she uses it in order to compare two people. Foster describes the suffix $k u$ as a comparative, but she does not explain its role. Based on her analysis, Stassen (1985: 137-138) classified it as an allative type. This classification is also problematic, as the construction with $k u$ is not an allative construction with a specific case marker. The function of $k u$ is to increase the valence and to allow the introduction of an additional argument, which is an applicative process. The comparative meaning is a consequence of the applicative: the first participant applies his quality (expressed by the adjective predicate) to the second participant introduced by the applicative $k u$.

This construction was not described in the grammars of the sixteenth century and is now seldom found. It corresponds to the agglutinative and derivative characteristics of the language. The standard NP functions as the direct object of the predicate, as in the verbal construction of Lengua de Michoacan, in example (15). It is possible to hypothesize that this construction existed in Lengua de Michoacan, but later fell into disuse.

\subsection{Synthesis}

The four types and the different constructions are summed up in Table 1: 


\begin{tabular}{|c|c|c|c|}
\hline TYPE P & TYPE PL & TYPE CP & TYPE A \\
\hline Particle type & $\begin{array}{l}\text { Particle type with a } \\
\text { locative }\end{array}$ & $\begin{array}{l}\text { Mixed coordination } \\
\text { and particle type }\end{array}$ & Applicative type \\
\hline $\begin{array}{l}\text { P1 Borrowing } \\
\text { mas...ke }\end{array}$ & $\begin{array}{l}\text { PL1 Source localization } \\
\text { - Borrowing } \\
\text { mas...ke...de }\end{array}$ & $\begin{array}{l}\text { CP1 Borrowing } \\
\text { mas...ka no }\end{array}$ & $\begin{array}{l}\text { Applicative } \\
-k u\end{array}$ \\
\hline $\begin{array}{l}\text { P2 Replication } \\
\text { sániteru...exka }\end{array}$ & $\begin{array}{l}\text { PL2 Source localization } \\
\text { - Replication } \\
\text { sániteru...ke...de }\end{array}$ & $\begin{array}{l}\text { CP2 Replication } \\
\text { sániteru...ka no }\end{array}$ & \\
\hline $\begin{array}{l}\text { P3 Replication+ } \\
\text { borrowing } \\
\text { sániteru...ke }\end{array}$ & $\begin{array}{l}\text { PL3 Static localization } \\
\text { - Borrowing } \\
\text { mas...ke...entre }\end{array}$ & & \\
\hline $\begin{array}{l}\text { P4 Replication+ } \\
\text { borrowing and } \\
\text { replication } \\
\text { sániteru...ke...exka }\end{array}$ & & & \\
\hline
\end{tabular}

Table 1. Comparison: types and sub-types

Purepecha has always used diverse and heterogeneous means to express the cognitive activity of assigning a graded position on a predicative scale. In the sixteenth century, Lengua de Michoacan had two types; today, the system has four types (table 2). This language shows two clear tendencies, namely the use of diverse strategies and the use of mixed constructions (PL and CP).

\begin{tabular}{|c|c|}
\hline Lengua de Michoacan & Purepecha \\
\hline Verbal type & (is replaced by) Particle type \\
\hline \multicolumn{2}{|l|}{ Coordination type + Verbal type } \\
\hline \multicolumn{2}{|r|}{ (is replaced by) } \\
\hline \multicolumn{2}{|r|}{ Coordination type + Particle type } \\
\hline \multicolumn{2}{|r|}{ Particle type with a locative phrase } \\
\hline$?$ & Applicative type \\
\hline
\end{tabular}

Table 2. Comparative types in Lengua de Michoacan and in Purepecha 
All of the types found in modern Purepecha are constructions created on the model of Spanish, except the construction with entre, which is an innovation not attested in Spanish or in Purepecha, and the applicative type, which may have been present in Lengua de Michoacan. These two constructions have yet another characteristic - they are not taken into account in the cross-linguistic studies referred to (Andersen 1983; Stassen 1985; Heine 1997; Cuzzolin and Lehmann 2004).

\section{Geographical distribution}

\subsection{The emergence of multiple options in each village}

The complexity and diversity found in Purepecha are due to a historical shift, as claimed by Stassen (1985: 326), but are also, above all, the result of language contact, that is, contact with Spanish. The particle type is the only one that appears as the sole option in a village. It is found in $100 \%$ of the villages in the sample (map 2) and is the sole option in $64.7 \%$ of the villages. In $35.3 \%$ of the villages, multiple options are available, and six possibilities exist (see table 3). In table 3, bold type indicates the unmarked choice, that is, the most frequent construction that occurs in all the contexts and among all the speakers. In the majority of the multiple options, the particle type $(\mathrm{P})$ is the unmarked possibility, except in certain villages in which the particle type with a locative (PL) is the unmarked type. The most frequent possibility is the double option, which represents $63.7 \%$ of the multiple options, then the triple option, with $31.2 \%$, and finally the quadruple option, with $5.1 \%$. 


\begin{tabular}{|l}
\hline Double option \\
1) $\mathbf{P}-\mathrm{CP}(9.8 \%)$ \\
2) $\mathbf{P}-\mathrm{PL}(5.8 \%)$ \\
3) $\mathbf{P L}-\mathrm{P}(3.9 \%)$ \\
4) $\mathbf{P}-\mathrm{A}(1.9 \%)$ \\
Triple option \\
4) $\mathbf{P}-\mathrm{PL}, \mathrm{CP}(7.8 \%)$ \\
5) $\mathbf{P L}-\mathrm{P}, \mathrm{CP}(3.9 \%)$ \\
Quadruple option \\
6) $\mathbf{P}-\mathrm{PL}, \mathrm{CP}, \mathrm{A}(1.9 \%)$
\end{tabular}

Table 3. Multiple options

Let us examine two relevant situations - the villages in which PL is the unmarked option and the village that exhibits a quadruple option.

The villages in which PL is the unmarked choice are located to the north of Lake Patzcuaro: Santa $\mathrm{Fe}$ de la Laguna, Chupícuaro, San Jerónimo P'urhenchecuaro and San Andrés Tziróndaro. The last of these is the only one that also uses the innovative construction with mas...ke...entre (subtype PL3). These four villages constitute a sub-area that exhibits great vitality (unlike the rest of that area); the people - even the young people - speak Purepecha in everyday conversation. This unusual sociolinguistic situation in a region where Purepecha is generally losing ground is revealed in the strategy speakers adopt to try to distinguish themselves from others, by claiming to use Purepecha. This strategy is also mirrored on historical, social and cultural levels, especially in the village of Santa Fe de la Laguna, as speakers explore and use the vitality and creative possibilities of Purepecha. This is reinforced by the use of subtype P4, a Purepechized construction, in some villages of the Sierra and in Santa Fe de la Laguna, where Purepecha use is very dynamic. 
The case of the village that exhibits a quadruple option is an interesting one. Cucuchucho is a village to the east of Lake Patzcuaro where Purepecha is almost no longer used (9\% of Purepecha speakers), and only a few old people remember it. In order to revitalize the language some of its people are in contact with speakers in other villages. The multiplicity of the contacts perhaps encourages the diversity of constructions attested in this village.

\subsection{Syntax as a relevant level for mapping out geographic distribution}

The dialectological aim here is to show that the concrete distribution of these constructions highlights three levels of result, showing a complex and new aspect of Purepecha dialectology that until now has not been described (Chávez 2004, Friedrich 1975).

Absence of isoglosses, that is, the presence of a single type throughout the area. The particle type (type $\mathrm{P}$ ) is found everywhere, but the single construction belonging to this type that is found throughout the territory is the subtype P3, the construction with sániteru, the replication of the degree marker, and ke as the comparative marker. It is interesting to note that this construction is a linguistic compromise between the construction with the two native elements sániteru...ixki, the subtype P2, and the construction with the two elements borrowed from Spanish mas...ke, the subtype P1 (see map 2).

One isogloss separates the eastern area from the western one. Focusing on the particle type constructions, type $\mathrm{P}$, there is complementary distribution between the two subtypes P1 and P2: P1 is present in the eastern area and P2 in the western area (see map 2). There is another difference between these areas: in the eastern area, the strategies are heterogeneous, and include the four different types, while in the western area only the particle type is found (with the exception of the applicative type found in one village, see map 5). Types PL and CP only appear in the eastern area (see maps 3 and 4). It is worth noting that each linguistic area includes two geographical regions: the eastern area includes the regions of Zacapu and Lake 
Patzcuaro, and the western area includes the northwest valley of the eleven villages and the Sierra region. The borderline between the two areas corresponds to the geographical division (by mountains) stretching from Zacapu to the southeast of Pichátaro.

Clear sociolinguistic differences exist between the western and eastern areas. Census data (table 4) indicate some of them. In the eastern area, the use of Purepecha is diminishing, partly because older people address young people in Spanish. In the western area, the language has more vitality and is more frequently used in everyday conversation. In the western area, speakers prefer to use native elements, so they use the subtype P2 and never the subtype P1 with its Spanish elements. However, it is difficult to tell if a preexisting isogloss defined networks of interaction that may influence this distinction. No dialectological studies exist prior to the research of Friedrich (1971) and Chávez (2004), and these linguists do not mention this possibility.

\begin{tabular}{|l|c|c|}
\hline & WESTERN AREA & EASTERN AREA \\
\hline$\%$ of villages in which Purepecha is spoken & 68.8 & 31.2 \\
\hline $\begin{array}{l}\% \text { of speakers of Purepecha } \\
\text { \% of villages in which Purepecha speakers } \\
\text { are less than 50\% }\end{array}$ & 45.5 & 23 \\
\hline $\begin{array}{l}\% \text { of villages in which Purepecha speakers } \\
\text { are more than 50\% }\end{array}$ & 54.6 & 38.3 \\
\hline
\end{tabular}

Table 4. Sociolinguistic data (Census of INEGI 2005)

A specific sub-area. One specific sub-area has been pointed out, to the north of Lake Patzcuaro, that is, the villages in which PL type is the unmarked choice (see section 6.1.). This sub-area has a different sociolinguistic situation from the other eastern area villages: here Purepecha is the everyday conversation language.

\subsection{A multi-layered perspective}

The integration of dialectology, typology, and contact linguistics offers new insights into many linguistic puzzles. 
Generally, contact linguistics studies explore the effects of contact on one or several languages. In this article, the effects of contact have been explored from a new perspective, taking a cross-dialectal perspective and using typology as a reference frame. The result allows us to argue that the effect of contact is not a unitary process, but can exhibit geographic specificity.

What is relevant for dialectology is that the inclusion of three linguistic domains in this study makes it possible to define dialectal areas for Purepecha unlike those claimed by Friedrich $(1971,1975)$ and Chávez (2004). The results found in this case study are not isolated; other examples, such as the position of the indefinite article in noun phrases, have similar results (Chamoreau 2012a). This is therefore an important advance toward a more fine-grained knowledge of the geographical distribution of Purepecha.

Another crucial fact is that the syntactic focus of dialectal research reveals the dynamic of current Purepecha. The result is thus not static and uni-level but dynamic and multi-dimensional. This multi-layered perspective displays three superimposed levels of organization.

- The first level exhibits an absence of isogloss, that is, the presence of a construction throughout the area.

- The second level exhibits one isogloss that separates the eastern area from the western one.

- The third level exhibits a sub-area with linguistic specificities, which is also known for its social, cultural, and historical uniqueness.

Each level has its own importance: The first level is clearly the outcome of the contact-induced process; the second level displays different linguistic strategies; the third level has a sociolinguistic and historical source. The complementary features of these superimposed levels create a multi-layered perspective and show the relevance of integrating dialectology, typology, and contact linguistics together for their mutual advantage. 


\section{Abbreviations}

$\begin{array}{ll}\text { A } & \text { Ergative case marker } \\ \text { ABL } & \text { Ablative } \\ \text { AOR } & \text { Aorist } \\ \text { APP } & \text { Applicative } \\ \text { ASS } & \text { Assertive } \\ \text { ATTRIB } & \text { Attributive } \\ \text { B } & \text { Absolutive case marker } \\ \text { CAUS } & \text { Causative } \\ \text { CENTRIP } & \text { Centripetal } \\ \text { CL } & \text { Clitic } \\ \text { COMPAR } & \text { Comparative } \\ \text { DEM } & \text { Demonstrative } \\ \text { DET } & \text { Determiner } \\ \text { FEM } & \text { Feminine } \\ \text { FOC } & \text { Focus } \\ \text { FT } & \text { Formative } \\ \text { FUT } & \text { Future } \\ \text { HAB } & \text { Habitual } \\ \text { INCH } & \text { Inchoative } \\ \text { IND } & \text { Independent } \\ \text { INDIC } & \text { Indicative } \\ \text { INF } & \text { Infinitive } \\ \text { INT } & \text { Interrogative } \\ \text { INTS } & \text { Intensive } \\ \text { KPOS } & \text { Kinship possessive } \\ \text { LOC } & \text { Locative } \\ \text { MASC } & \text { Masculine } \\ \text { MID } & \text { Middle } \\ \text { NEG } & \text { Negation } \\ \text { OBJ } & \text { Object } \\ & \end{array}$




$\begin{array}{ll}\text { PAST } & \text { Past } \\ \text { PL } & \text { Plural } \\ \text { POS } & \text { Possessive } \\ \text { PRED } & \text { Predicativizer } \\ \text { PRES } & \text { Present } \\ \text { SBJ } & \text { Subject } \\ \text { SG } & \text { Singular } \\ \text { TRANSF } & \text { Transfer }\end{array}$

\section{Villages}

$\begin{array}{ll}\text { AR } & \text { Arantepacua } \\ \text { CC } & \text { Cucuchucho } \\ \text { CN } & \text { Cuanajo } \\ \text { IH } & \text { Ihuatzio } \\ \text { JN } & \text { Janitzio } \\ \text { JR } & \text { Jarácuaro } \\ \text { OC } & \text { Ocumicho } \\ \text { SA } & \text { San Andrés Tziróndaro } \\ \text { TM } & \text { Teremendo }\end{array}$

\section{References}

Andersen, Paul. 1983. Word order typology and comparative constructions. Amsterdam/Philadelphia: John Benjamins Publishing Company.

Capistrán, Alejandra. 2002. Variaciones de orden de constituyentes en p'orhépecha. Topicalización y focalización. Del Cora al Maya Yucateco. Estudios lingüísticos sobre algunas lenguas indígenas mexicanas, P. Levy (ed.), 349-402. Mexico: UNAM.

Census INEGI. 2005.http://www.inegi.gob.mx/est/contenidos/espanol/sistemas/ conteo2005/ iter2005/selentcampoaspx 
Chamoreau, Claudine. 2005. Dialectología y dinámica: reflexiones a partir del purépecha. Trace 47: 61-81.

Chamoreau, Claudine. 2007. Grammatical borrowing in Purepecha. Grammatical borrowing in cross-linguistic perspective, Y. Matras and J. Sakel (eds.), 465480. Berlin: Mouton de Gruyter.

Chamoreau, Claudine. 2009a. Langues de Méso-Amérique. De la description et de l'explication multifactorielle de l'évolution linguistique à la dialectologie typologique. Habilitation à diriger des Recherches. Université Lumière Lyon 2, 17 December 2009.

Chamoreau, Claudine. 2009b. Hablemos purepecha, Wanté juchari anapu. Morelia: Universidad Intercultural Indígenas de Michoacán/IIHUMSNH/IRD/CCC-IFAL/Grupo Kw'anískuyarhani de Estudiosos del Pueblo Purépecha.

Chamoreau, Claudine. 2012a. Dialectology, typology, diachrony and contact linguistics. A multi-layered perspective in Purepecha. Sprachtypologie und Universalienforschung (STUF - Language Typology and Universals) 65, 1.

Chamoreau, Claudine. 2012b. Contact-induced change as an innovation. C. Chamoreau \& I. Léglise (eds). Dynamics of Contact-induced language change. Berlin: Mouton de Gryuter. 53-76.

Chávez Rivadeneyra, David. 2004. Aproximación a la dialectología de la lengua purépecha (MA thesis). Mexico: Centro de Investigaciones y Estudios Superiores en Antropología Social.

Craig, Colette. 1977. The Structure of Jacaltec. Austin: University of Texas Press.

Creissels, Denis. 2006. Syntaxe générale, une introduction typologique. Paris: Hermes.

Cuzzolin, Pierluigi and Christian Lehmann. 2004. Comparison and gradation. Nr. 155: $1212-1220$.

Dryer, Matthew. 2007. Word Order. Clause structure. Language typology and syntactic description, Vol. 1, T. Shopen (ed.). Cambridge: Cambridge University Press. (http://linguistics.buffalo.edu/people/faculty/dryer/dryer/ DryerShopenWordOrder.pdf) 
Estrada Fernández, Zarina. 2006. Clauses combining in Pima Bajo. Paper given at the Primer seminario de complejidad sintáctico. Mexico: University of Sonora.

Friedrich, Paul. 1971. Dialectal Variation in Tarascan Phonology. International Journal of American Linguistics 37(3): 164-187.

Friedrich, Paul. 1975. Dialectal Variation. A phonology of Tarascan, 106-158. Chicago: University of Chicago Press.

Galant, Michael Rene. 1998. Comparative constructions in Spanish and San Lucas Quiavini Zapotec. Ph.D. thesis, University of California, Los Angeles.

Gilberti, Maturino. 1987 [1558]. Arte de la lengua de Michuacan. Morelia: Fimax.

Heine, Bernd. 1994. Areal influence on grammaticalization. Language contact and language conflict, M. Pütz (ed.), 55-68. Amsterdam / Philadelphia: John Benjamins Publishing Company.

Heine, Bernd. 1997. Cognitive foundations of grammar. New York / Oxford: Oxford University Press.

Kortmann, Bernd (ed.). 2004. Dialectology meets typology: Dialect grammar from a cross-linguistic perspective. Amsterdam: Walter de Gruyter.

Launey, Michel. 1981. Introduction à la langue et à la littérature aztèques, tome 1: grammaire. Paris: L'Harmattan.

Lindenfeld, Jacqueline. 1971. Semantic categorization as a deterrent to grammatical borrowing: a Yaqui example. International Journal of American Linguistics 37(1): 6-14.

Nevalainen, Terttu, et al. (eds.). 2006. Types of Variation. Diachronic, dialectal and typological interfaces. Amsterdam: John Benjamins Publishing Company.

Pottier, Bernard. 1982. Comparaison: le même et l'autre. Modèles linguistiques 4(2): 41-48.

Rojas Nieto, Cecilia. 1990a. Comparación léxica, comparación sintagmática. Homenaje a Jorge A. Suárez. Lingüística indoamericana e hispánica, B. Garza Cuarón and P. Levy (eds.), 447-457. Mexico: El Colegio de México.

Rojas Nieto, Cecilia. 1990b. El término de las construcciones comparativas de desigualdad: de o que. Estudios de Lingüística de España y México, V. Demonte and B. Garza Cuarón (eds.), 225-241. Mexico: El Colegio de México / UNAM. 
Stassen, Leon. 1985. Comparison and Universal Grammar. Oxford: Basil Blackwell.

Stassen, Leon. 2001. Comparative constructions. Language typology and language universals: An international handbook, M. Haspelmath, E. König, W. Oesterreicher and W. Raible (eds.), 993-997. Berlin: Walter de Gruyter.

Stassen, Leon. 2005. Comparative constructions. The world atlas of language structures, M. Haspelmath, M. Dryer, D. Gil and B. Comrie (eds.), 490-491. Oxford: Oxford University Press.

Stolz, Christel and Thomas Stolz. 1995. Spanisch-amerindischer Sprachkontakt: Die 'Hispanisierung' mesoamerikanischer Komparationsstrukturen. Iberoamericana 19(2/3): 5-42.

Stolz, Christel and Thomas Stolz. 2001. Hispanicised Comparative Constructions in Indigenous Languages of Austronesia and the Americas. Lo propio y lo ajeno en las lenguas austronésicas y amerindias, K. Zimmerman and T. Stolz (eds.), 35-56. Frankfurt, Madrid: Vervuert, Iberoamericana.

Tersis, Nicole. 2008. Forme et sens des mots du Tunumiisut. Lexique inuit du Groenland Oriental. Louvain / Paris / Dudley: Peeters. 